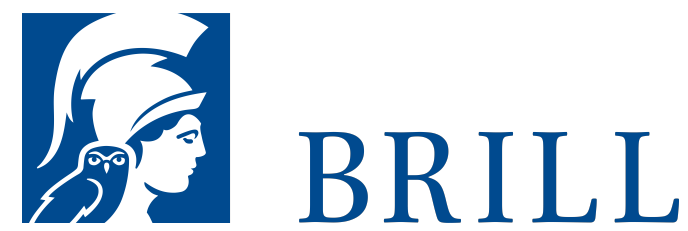

\title{
Pax Christi Deutschland im Kalten Krieg 1945-1957
}

Gründung, Selbstverständnis und »Vergangenheitsbewältigung «

Author: Jens Oboth

Nach zwei verheerenden Weltkriegen zählte die Annäherung zwischen Frankreich und Deutschland zu den entscheidenden Voraussetzungen für ein versöhntes Europa. Die katholische Friedensbewegung Pax Christi leistete dazu einen historisch bedeutsamen, lange übersehenen Beitrag. Der Autor beschreibt erstmals die konfliktreichen Auseinandersetzungen, die Pax Christi bei der Suche nach seinem politischen und religiösen Standort in der jungen Bundesrepublik durchlief. Die Annäherung an die »Last der Vergangenheit« wurde den deutschen Aktivisten durch die ausgestreckte Hand erleichtert, die ihnen von französischer Seite gereicht wurde. Dieser Lernprozess schuf die Grundlagen für spätere internationale Versöhnungsinitiativen mit NS-Opfern in den 196oer Jahren.

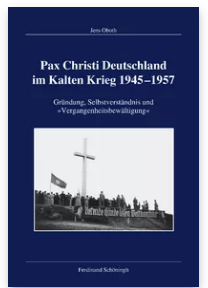

Pages: 503

Seiten, $5 \mathrm{~s} / \mathrm{w}$ und 40 farb. Abb., 1 s/w Tab.

Language:

German

Subjects:

General,

Theology and

World

Christianity

Publisher: Brill |

Schöningh

Series:

Veröffentlichungen

der Kommission

für Zeitgeschichte, Reihe B:

Forschungen,

Volume: 131

E-Book (PDF)

Released online: O2 Sep 2019

ISBN: 978-3-

657-78273-4

List price

Hardback

Publication date:

14 Jul 2017

ISBN: 978-3-

506-78273-1

List price 
Biographical Note

Jens Oboth ist Dozent an der Katholischen Akademie des Bistums Essen, »Die Wolfsburg «.

For more information see brill.com

\begin{abstract}
Order information: Order online at brill.com
+44330 333 0049 | customerservices@brill.com

Submission information: brill.com/authors
\end{abstract}

Titles published by Brill | Fink, Brill | mentis or Brill| Schöningh: +49(o)71 5413279216 | brill@brocom.de 